\title{
Implementasi Pendidikan Karakter dalam Pembelajaran Matematika dengan Menggunakan Model Pembelajaran Kooperatif Tipe Team Assisted Individualization
}

\author{
${ }^{1}$ Lintal Muna \\ 2 Yani Djawa \\ ${ }_{1}^{1}$ Program Studi Pendidikan Biologi, FTIK, IAIN Ternate \\ ${ }^{2}$ Program Studi Pendidikan Matematika, FTIK, IAIN Ternate \\ E-mail:muna.lintal@gmail.com
}

\begin{abstract}
In the era of globalization we need the implementation of character education for selflimiting, given that in the era of globalization, it is difficult to recognize cultural boundaries. Therefore, it takes an integrated character education on the subjects, thus indirectly the character education has been applied. To implement an integrated character education in the subjects, required learning model that suits the character that will be applied. Team assisted individualization is one type of cooperative learning model in a way students work in cooperative learning groups and is responsible for setting and checking on a regular basis, helping each other solve problems and to encourage each other to excel. The purpose of this study is not to implement character education in mathematics using cooperative learning model Team Assisted Individualization (TAI) and know the results of students of class V SD Negeri 3 Weda. This study is a class action (Classroom Action Research) collaborative and in the form of a cycle. The subject of research is a class V SD Negeri 3 Vedas. The instrument used was a test, observation sheets, interview, and documentation. The results showed that an increase in the learning outcomes of pre-cycle where students learning completeness 0\% increase in the first cycle to the second cycle of $40 \%$ and $76 \%$. The same thing can be seen in the ability of teachers to manage the classroom, in the first cycle teachers value increased in the second cycle of 3.75 to 4.58 with both categories. For the implementation of the integrated character education in mathematics can be seen in the first cycle of $98.67 \%$ the percentage of character discipline, teamwork $96 \%$, and the responsibilities of $86.71 \%$. In the second cycle, $98.76 \%$ of students have had the character of discipline, $96.90 \%$ students have the character of cooperation, and $88.89 \%$ of students have had the character of responsibility.
\end{abstract}

Keywords: Character Education, TAI type of cooperative learning model, learning of mathematics

\footnotetext{
Abstrak

Di era globalisasi seperti sekarang ini kita butuh penerapan pendidikan karakter untuk membatasi diri, mengingat bahwa di era globalisasi sulit untuk mengenali batas-batas budaya. Oleh karena itu, dibutuhkan pendidikan karakter yang terintegrasi pada mata pelajaran, sehingga secara tidak langsung pendidikan karakter tersebut telah diterapkan. Untuk menerapkan pendidikan karakter yang terintegrasi dalam mata pelajaran, diperlukan model pembelajaran yang sesuai dengan karakter yang akan diterapkan. Team assisted individualization merupakan salah satu tipe dari model pembelajaran kooperatif dengan cara siswa bekerja dalam kelompok-kelompok belajar kooperatif dan bertanggung jawab dalam pengaturan dan pengecekan secara rutin, saling membantu memecahkan masalah dan saling mendorong untuk berprestasi. Tujuan penelitian ini adalah mengimplementasikan
} 
pendidikan karakter dalam pembelajaran matematika dengan menggunakan model pembelajaran kooperatif tipe Team Assisted Individualization (TAI) dan mengetahui hasil belajar siswa kelas V SD Negeri 3 Weda. Penelitian ini merupakan penelitian tindakan kelas (Classroom Action Research) yang bersifat kolaboratif dan dalam bentuk siklus. Adapun yang menjadi subjek penelitian yaitu kelas V SD Negeri 3 Weda. Instrument yang digunakan adalah tes, lembar observasi, wawancara, dan dokumentasi. Implementasi pendidikan karakter dalam pembelajaran matematika dengan menggunakan model pembelajaran kooperatif tipe TAI dilakukan dengan langkah-langkah sebagai berikut: 1) pembagian materi dan LKS kepada siswa secara individual; 2) guru menyampaikan materi secara singkat; 3) siswa memahami materi dan mengerjakan LKS secara individual; 3) pembagian kelompok, yang terdiri dari 5 siswa; 4) di dalam kelompok, siswa saling memeriksa jawaban LKS; 5) presentasi oleh siswa dengan nilai tertinggi; 6) guru bersama dengan siswa membuat kesimpulan terkait dengan materi; 7) memberikan penghargaan kepada siswa dengan hasil belajar tertinggi. Model pembelajaran tersebut dapat maningkatkan hasil belajar dan karakter siswa. Hasil belajar siswa menunjukkan peningkatan dari pra siklus 0\% meningkat pada siklus I menjadi 40\% dan siklus II 76\%. Hal yang sama dapat dilihat pada kemampuan guru dalam mengelola kelas, pada siklus I nilai guru 3,75 meningkat pada siklus II menjadi 4,58 dengan kategori baik. Untuk implementasi pendidikan karakter yang terintegrasi dalam pembelajaran matematika dapat dilihat pada siklus I persentase karakter disiplin 98.67\%, kerjasama 96\%, dan tanggung jawab $86.71 \%$. Pada siklus II, 98.76\% siswa telah memiliki karakter disiplin, $96.90 \%$ siswa memiliki karakter kerjasama, dan $88.89 \%$ siswa telah memiliki karakter tanggung jawab.

Kata Kunci: Pendidikan karakter, model pembelajaran kooperatif tipe TAI, pembelajaran matematika

\section{Pendahuluan}

Undang-Undang Nomor 20 Tahun 2003 Pasal 3 tentang Sistem Pendidikan Nasional menyatakan bahwa pendidikan nasional berfungsi mengembangkan kemampuan dan membentuk karakter serta peradaban bangsa yang bermartabat dalam rangka mencerdaskan kehidupan bangsa. ${ }^{1}$ Berdasarkan UU tersebut, maka jelas bahwa pendidikan karakter perlu diterapkan di setiap lembaga pendidikan. Pentingnya penerapan pendidikan karakter ini dinyatakan oleh Azzet yakni pendidikan karakter penting untuk semua tingkat pendidikan, dari sekolah dasar hingga perguruan tinggi. Apabila karakter seseorang telah terbentuk sejak usia dini, ketika dewasa tidak akan mudah berubah meski godaan atau rayuan datang begitu menggiurkan. Dengan adanya pendidikan karakter semenjak usia dini, diharapkan persoalan mendasar dalam dunia pendidikan yang akhir-akhir ini sering menjadi keprihatinan bersama dapat diatasi. ${ }^{2}$

\footnotetext{
1Undang-Undang RI Nomor 20 Tahun 2003, Sistem Pendidikan Nasional Pasal 3

2 Akhmad Muhaimin Azzet, Urgensi Pendidikan Karakter di Indonesia, Cet. I, (Jogjakarta: Ar-Ruzz Media, 2011), h. 15-16
} 


\section{Implementasi Pendidikan Karakter...}

Masalah yang dihadapi lembaga pendidikan adalah tidak semua lembaga pendidikan menerapkan kurikulum 2013 yang di dalamnya terdapat pendidikan karakter. Namun, hal tersebut terjawab dengan adanya pernyataan Wiyono yang menyatakan bahwa implementasi pendidikan karakter di sekolah sebenarnya tidak harus dengan cara menambah mata pelajaran baru tentang pendidikan karakter secara eksplisit, karena bisa dilakukan dengan cara meninjau kembali dan menajamkan kurikulum sehingga memuat pendidikan karakter dan nilai-nilai agama yang akan ditransformasikan kepada peserta didik. $^{3}$ Dengan demikian jelas bahwa pendidikan karakter harus diterapkan dalam proses pembelajaran. Tantangan selanjutnya bagi lembaga pendidikan yang tidak menerapkan kurikulum 2013 adalah teknik guru dalam mengintegrasikan pendidikan karakter dalam proses pembelajaran. Untuk mengintegrasikan pendidikan karakter dalam pembelajaran, khusunya pembelajaran matematika di Sekolah Dasar diperlukan adanya model pembelajaran yang tepat sesuai dengan karakter yang akan dibentuk.

Karakteristik anak sekolah dasar secara umum sebagaimana dikemukakan oleh Basset dkk dalam Mulyani Sumantri dan Johar Permana, yaitu: (1) Anak SD secara ilmiah memiliki rasa ingin tahu yang kuat dan tertarik pada dunia sekitar yang mengelilingi diri mereka sendiri, (2) mereka senang bermain dan lebih suka bergembira/riang, (3) mereka suka mengatur dirinya untuk menangani berbagai hal, mengeksplorasi suatu situasi dan mencobakan usaha-usaha baru, (4) mereka bergetar perasaannya dan terdorong untuk berprestasi sebagaimana mereka tidak suka mengalami ketidakpuasan dan menolak kegagalan-kegagalan, (5) mereka belajar secara efektif ketika mereka merasa puas dengan situasi yang terjadi, dan (6) mereka belajar dengan cara bekerja, mengobservasi, berinisiatif, dan mengajar anak-anak lainnya.. ${ }^{4}$ Berdasarkan hal-hal tersebut, maka model pembelajaran yang sesuai untuk pengintegrasian pendidikan karakter dalam

\footnotetext{
${ }^{3}$ Hadi Wiyono, Pendidikan Karakter Dalam Bingkai Pembelajaran di Sekolah, (Jurnal Ilmiah CIVIS, Vol II, No 2, 2012)

${ }^{4}$ Mulyani Sumantri dan Johar Permana, Strategi Belajar Mengajar. (Bandung: CV Maulana, 2011), h. 11
} 
pembelajaran matematika adalah model pembelajaran kooperatif tipe Team Assisted Individualization (TAI).

Model pembelajaran kooperatif tipe Team Assisted Individualization (TAI) yaitu model pembelajaran dimana siswa dengan kemampuan yang berbeda-beda dapat bekerjasama dalam menyelesaikan tugas secara individual dan membantu anggota kelompok mereka yang mengalami kesulitan. Berdasarkan hasil wawancara dengan guru SD Negeri 3 Weda diperoleh informasi bahwa guru-guru di SD Negeri 3 Weda belum sepenuhnya mengimplementasikan pendidikan karakter dalam pembelajaran, juga model pembelajaran yang digunakan kurang variatif. Hanya guru-guru tertentu yang telah mengintegrasikan pendidikan karakter dalam pembelajaran dengan menggunakan model pembelajaran tertentu. Berdasarkan masalah tersebut, maka peneliti tertarik untuk melakukan penelitian dengan judul " Implementasi Pendidikan Karakter dalam Pembelajaran Matematika dengan Menggunakan Model Pembelajaran Kooperatif Tipe Team Assisted Individualization (TAI) di SD Negeri 3 Weda"

\section{Kerangka Teoretis}

Pendidikan karakter pada dasarnya merupakan upaya dalam proses menginternalisasikan, menghadirkan, menyemaikan, dan mengembangkan nilai-nilai kebaikan pada diri peserta didik. Dengan internalisasi nilai-nilai kebajikan pada diri peserta didik, diharapkan dapat mewujudkan perilaku baik. $^{5}$ Ginanjar menyatakan bahwa ada tujuh nilai karakter utama yang harus dikembangkan dalam kehidupan manusia, yaitu jujur, tanggung jawab, visioner, disiplin, kerja sama, adil, dan peduli sesama. ${ }^{6}$

Washin, B \& Salend. J. S. mendeskripsikan bahwa TAI adalah suatu sistem pembelajaran yang menuntun siswa dengan kemampuan yang berbeda-beda dapat bekerjasama dalam menyelesaikan tugas secara individual dan membantu anggota kelompok mereka yang mengalami

\footnotetext{
${ }^{5}$ Novan Ardy Wiyani, Membumikan Pendidikan Karakter di sekolah di SD, Cetakan I (Jogjakarta: Ar-Ruzz Media, 2013), h.70

${ }^{6}$ Dharma Kesuma, dkk, Pendidikan Karakter: Kajian Teori dan Praktik di Sekolah, Cet. ke-1, (Bandung: PT. Remaja Rosdakarya, 2011), h. 13
} 


\section{Implementasi Pendidikan Karakter...}

kesulitan. ${ }^{7}$ Model pembelajaran koopertaif tipe TAI mempunyai tujuan bahwa keberhasilan individu ditentukan atau dipengaruhi oleh keberhasilan kelompoknya. ${ }^{8}$ Dalam penelitiannya, Slavin mengemukakan bahwa pembelajaran TAI mempunyai pengaruh yang positif terhadap sikap, perilaku, dan meningkatkan prestasi siswa yang terlambat secara akademis. ${ }^{9}$ Hasil belajar menurut Sudjana dalam Fitriana adalah kemampuan yang dimiliki siswa setelah ia menerima pengalaman belajarnya. ${ }^{10}$

\section{Metode dan Hasil Penelitian}

Penelitian ini merupakan penelitian tindakan kelas (Classroom Action Research) dengan ciri kolaboratif dan dalam bentuk siklus. Lokasi penelitian yaitu SD Negeri 3 Weda dengan subjek penelitian siswa kelas V yang berjumlah 25 siswa. Penelitian ini dimulai dari identifikasi masalah, menyusun perencanaan, melaksanakan tindakan, melakukan observasi, dan mengadakan refleksi. ${ }^{11}$ Instrumen yang digunakan dalam penelitian ini antara lain test (pre test dan post test), observasi, wawancara (sebagai data pendukung), dan dokumentasi. Data dianalisis secara kualitatif dengan cara:

1. Untuk mencari tingkat penguasaan (ketuntasan) siswa secara individual terhadap materi yang diajarkan yaitu dengan membuat kisi-kisi jawaban, mengingat bahwa soal dalam bentuk essay.

2. Untuk mencari ketuntasan siswa secara klasikal, yaitu dengan rumus:

Ketuntasanklasikal $=\frac{\text { jumlah siswayang tuntas }}{\text { jumlahkeseluruhan siswa }} \times 100 \%$

7.Washin, B \& Salend. J. S, Team-Assisted Individualization with Handicapped Adjudicated Youth. Artikel. Diakses pada tanggal 01 Desember 2015 http://findarticles.com/p/articles/mi hb3130/is n2 v55/ai n285828510.

8 Slavin, R.E. Team Assisted Cooperative Learning and individualized Instruction In The Mainstreamed Classroom. Search of journals. Hammil Institute on Disabilities. 2010. Diakses tanggal 01 Desember 2015. http://rse.sagepub.com/content/5/6/33.abstract.Slavin,

9 Slavin, R.E. Team-Assisted Individualization: A Cooperative Learning Solution for Adaptive Instruction in Mathematics. Artikel. 1983, h. 1, Diakses tanggal 01 Desember 2015. http://rse.sagepub.com/content/5/6/33.abstract.Slavin

10 Ida Fitriana, 2005. Meningkatkan Hasil Belajar dan Sikap Konstruktif Terhadap Pembelajaran Waktu, Jarak, dan Kecepatan Melalui Model Pembelajaran Kooperatif STAD (Student Team Achievement Division) pada Siswa SMPN 2 Demak Tahun 2004/2005. Semarang: UNNES. Diakses pada 10 Oktober 2015

${ }^{11}$ Wina Sanjaya, Penelitian Tindakan Kelas, Edisi 1, Cet. 3, (Jakarta: Kencana, 2011), h. 53 
3. Untuk menilai aktivitas siswa digunakan penilaian "ya atau tidak", sedangkan untuk penilaian terhadap aktivitas guru digunakan skala 1-5 yang diinterpretasikan sebagai berikut: $5=$ sangat baik, $4=$ baik, $3=$ cukup baik, 2 = kurang baik, 1 = sangat kurang

\section{Implementasi Pendidikan Karakter dalam Pembelajaran Matematika}

Implementasi pendidikan karakter ini dilihat mulai dari awal sampai dengan akhir proses pembelajaran. Pelaksanaan pembelajaran dimulai dengan pemberian pengantar materi oleh guru, pemberian LKS kepada siswa untuk dikerjakan secara individual, kemudian siswa membentuk kelompok dan berdiskusi dengan teman kelompok dan menjelaskan kepada teman yang belum paham dengan materi yang diajarkan. Hal tersebut dilaksanakan sesuai dengan waktu yang telah ditentukan. Tahap selanjutnya adalah presentasi hasil diskusi kelompok dan pemberian penghargaan. Penelitian ini dilaksanakan dengan dua siklus, karena pada siklus kedua ketuntasan belajar siswa secara individual telah memenuhi KKM yaitu $\geq 67$ dan secara klasikal $\geq$ $70 \%$. Selain itu, pada siklus II juga telah terjadi peningkatan karakter siswa, sehingga secara proses siklus ini dapat dihentikan.

Adapun hasil penilaian observer terhadap pendidikan karakter siswa selama proses pembelajaran siklus I yaitu bahwa karakter disiplin, kerjasama, dan tanggung jawab telah dimiliki oleh siswa kelas V SD Negeri 3 Weda dengan prosentase karakter disiplin 98.67\%, kerjasama 96\%, dan tanggung jawab 86.71\%. Pada siklus II, 98.76\% siswa telah memiliki karakter disiplin, 96.90\% siswa memiliki karakter kerjasama, dan 88.89\% siswa telah memiliki karakter tanggung jawab. Hal ini diduga bahwa model pembelajaran kooperatif tipe TAI ini mampu memotivasi siswa untuk meningkatkan karakter disiplin, kerjasama, dan tanggung jawab. Hal ini sesuai dengan pernyataan Slavin bahwa model pembelajaran kooperatif tipe TAI memberikan pengaruh yang positif terhadap sikap dan perilaku siswa. ${ }^{12}$

\footnotetext{
${ }^{12}$ Ibid, Slavin, R.E. Team-Assisted Individualization: A Cooperative Learning Solution for Adaptive Instruction in Mathematics. Artikel. 1983
} 


\section{Implementasi Pendidikan Karakter...}

Lebih lanjut Asosiasi Lembaga Pendidikan Tenaga Kependidikan Indonesia menyatakan bahwa prinsip dasar dalam pendidikan karakter yaitu pembelajaran dibangun sebagai proses kultural yang prosesnya tidaklah linier dan bukan pula berupa mata pelajaran "Pendidikan Karakter". Pengembangan karakter menyatu dalam proses pendidikan secara keseluruhan. ${ }^{13}$ Artinya bahwa pendidikan karakter ini tidak selalu diterapkan pada satu mata pelajaran khusus untuk pendidikan karakter, akan tetapi dapat diterapkan pada semua mata pelajaran. Adapun Persentase karakter siswa pada siklus I dan II dapat dilihat pada Tabel 1 dan Tabel 2 berikut:

Tabel 1. Persentase Karakter Siswa pada Siklus I

\begin{tabular}{|c|c|c|c|c|}
\hline \multirow{2}{*}{ No } & \multirow{2}{*}{ Aspek yang Diamati } & \multicolumn{2}{|c|}{ Siklus I } & \multirow{2}{*}{$\begin{array}{c}\text { Rata- } \\
\text { Rata (\%) }\end{array}$} \\
\hline & & Part I & Part II & \\
\hline 1 & Displin masuk kelas tepat waktu & 100 & 100 & 98,67 \\
\hline 2 & Disiplin dalam mengikuti pelajaran & 100 & 92 & \\
\hline 3 & Fokus belajar & 100 & 100 & \\
\hline 4 & Memberi penjelasan kepada teman & 100 & 96 & 96 \\
\hline 5 & Terlibat aktif dalam kelompok & 92 & 88 & \\
\hline 6 & Menyelesaikan tugas dalam diskusi & 100 & 100 & \\
\hline 7 & Tanggung jawab dalam tugas & 100 & 100 & 86,71 \\
\hline 8 & Tanggung jawab dalam presentasi hasil & 68 & 60 & \\
\hline 9 & Tanggung jawab menjaga ketertiban & 96,29 & 96 & \\
\hline
\end{tabular}

Tabel 2. Persentase Karakter Siswa pada Siklus II

\begin{tabular}{|c|c|c|c|c|}
\hline \multirow{2}{*}{ No } & \multirow{2}{*}{ Aspek yang Diamati } & \multicolumn{2}{|c|}{ Siklus I } & \multirow{2}{*}{$\begin{array}{c}\text { Rata- } \\
\text { Rata (\%) }\end{array}$} \\
\hline & & Part I & Part II & \\
\hline 1 & Displin masuk kelas tepat waktu & 100 & 100 & \multirow{3}{*}{98,76} \\
\hline 2 & Disiplin dalam mengikuti pelajaran & 96.29 & 100 & \\
\hline 3 & Fokus belajar & 96.29 & 100 & \\
\hline 4 & Memberi penjelasan kepada teman & 96.26 & 100 & \multirow{3}{*}{96,90} \\
\hline 5 & Terlibat aktif dalam kelompok & 96.29 & 96.29 & \\
\hline 6 & Menyelesaikan tugas dalam diskusi & 96.29 & 96.29 & \\
\hline 7 & Tanggung jawab dalam tugas & 100 & 100 & \multirow{3}{*}{88,89} \\
\hline 8 & Tanggung jawab dalam presentasi hasil & 66.67 & 66.67 & \\
\hline 9 & Tanggung jawab menjaga ketertiban & 100 & 100 & \\
\hline
\end{tabular}

\section{Hasil Belajar Siswa Melalui Implementasi Pendidikan Karakter}

\footnotetext{
${ }^{13}$ Tim Asosiasi Lembaga Pendidikan Tenaga Kependidikan Indonesia, Pemikiran tentang Pendidikan Karakter dalam Bingkai Utuh Sistem Pendidikan Nasional, (Jakarta, 2009)
} 
Hasil belajar siswa kelas V SD Negeri 3 Weda dengan adanya implementasi pendidikan karakter dengan model pembelajaran kooperatif tipe TAI menunjukkan peningkatan mulai dari pra siklus, siklus I, dan siklus II. Hasil belajar siswa pada pra siklus yaitu tidak ada siswa yang tuntas belajar dengan nilai KKM individual 67 dan persentase ketuntasan kelas sebesar 70\%. Ketuntasan belajar siswa pada siklus I sebesar $40 \%$, dan siklus II 76\%. Hal ini menunjukkan bahwa pendidikan karakter yang terintegrasi pada pembelajaran Matematika dengan menggunakan model pembelajaran kooperatif tipe TAI mampu meningkatkan hasil belajar siswa kelas V SD Negeri 3 Weda. Adapun hasil belajar siswa dalam pembelajaran Matematika pada materi bangun datar sederhana dengan menggunakan model pembelajaran kooperatif tipe TAI dapat dilihat pada diagram di bawah ini.

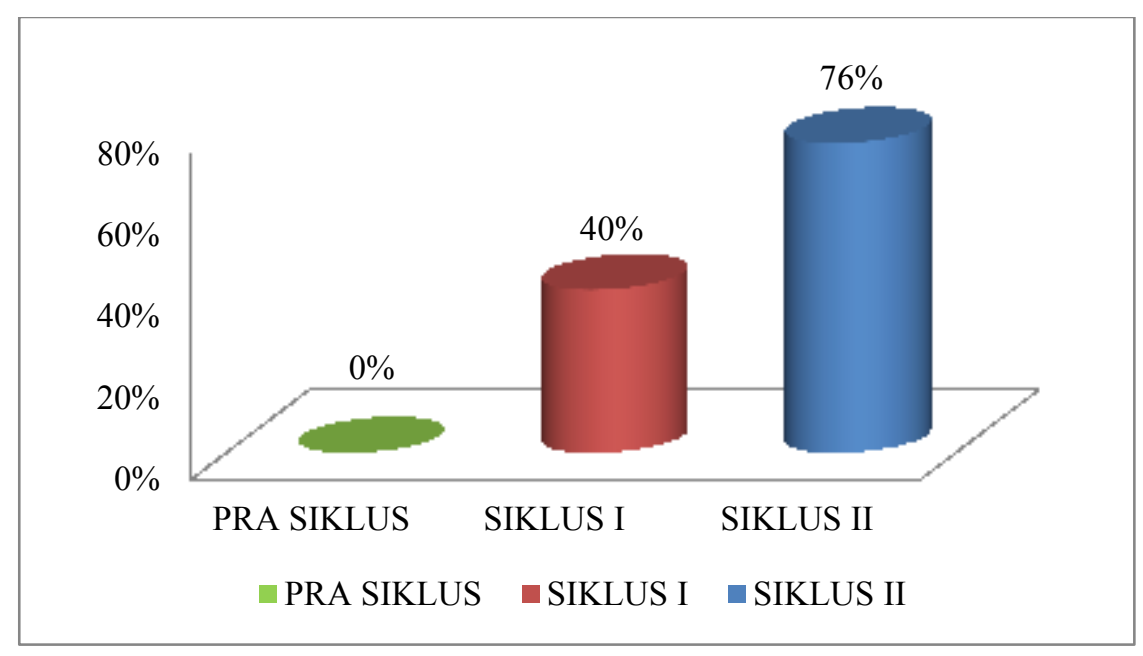

Gambar 1. Diagram hasil belajar siswa

Refleksi pada siklus I:

a. Nilai siswa belum mencapai KKM yang telah ditentukan, dengan ketuntasan individual 67 dan klasikal 70\%.

b. Nilai untuk kemampuan guru dalam menyajikan materi secara singkat dengan mengaitkan dengan pengetahuan prasyarat siswa masih kurang

c. Pengkondisian waktu belum tertata dengan baik, sehingga siswa merasa batas waktu yang diberikan kurang lama.

d. Pemahaman siswa terhadap materi masih kurang 


\section{Implementasi Pendidikan Karakter...}

e. Siswa tidak memahami kata-kata yang tercantum dalam LKS, misalnya "disimpulkan, sudut yang berimpit, dll"

Kemampuan guru dalam mengelola kelas selama proses pembelajaran berlangsung mengalami peningkatan pada siklus I dengan nilai rata-rata 3.75 meningkat pada siklus II menjadi 4.58 dengan kategori baik. Rincian selanjutnya dapat dilihat pada Tabel 3 dan Tabel 4 berikut:

Tabel 3. Kemampuan guru dalam mengelola kelas pada siklus I

\begin{tabular}{|c|c|c|c|c|}
\hline \multirow{3}{*}{ No } & \multicolumn{4}{|l|}{ SIKLUS I } \\
\hline & \multirow[b]{2}{*}{ Aspek yang dinilai } & Pert I & Pert II & \multirow{2}{*}{$\begin{array}{c}\text { Katego } \\
\text { ri }\end{array}$} \\
\hline & & $\begin{array}{l}\text { Rata- } \\
\text { Rata }\end{array}$ & $\begin{array}{l}\text { Rata- } \\
\text { Rata }\end{array}$ & \\
\hline \multirow[t]{4}{*}{ I } & Kegiatan Awal: & & & \\
\hline & $\begin{array}{l}\text { a) Kemampuan membuka pelajaran } \\
\text { dengan do'a dan salam }\end{array}$ & 5.00 & 5.00 & $\begin{array}{c}\text { Sangat } \\
\text { Baik }\end{array}$ \\
\hline & $\begin{array}{l}\text { b) Kemampuan mengkomunikasikan } \\
\text { tujuan pembelajaran }\end{array}$ & 4.00 & 4.00 & Baik \\
\hline & c) Kemampuan memotivasi siswa & 4.00 & 4.00 & Baik \\
\hline \multirow[t]{6}{*}{ II } & Kegiatan Inti: & & & \\
\hline & $\begin{array}{l}\text { a) Kemampuan menyajikan materi } \\
\text { secara singkat dengan mengaitkan } \\
\text { dengan pengetahuan prasyarat siswa }\end{array}$ & 2.00 & 2.00 & $\begin{array}{c}\text { Kuran } \\
\mathrm{g}\end{array}$ \\
\hline & $\begin{array}{l}\text { b) Kemampuan membagikan LKS dan } \\
\text { media pembelajaran }\end{array}$ & 4.00 & 4.00 & Baik \\
\hline & $\begin{array}{l}\text { c) Kemampuan mengarahkan siswa } \\
\text { untuk berkelompok dan menemukan } \\
\text { jawaban serta menyelesaikan LKS, } \\
\text { dengan memberikan bantuan } \\
\text { terbatas. }\end{array}$ & 3.00 & 3.00 & Cukup \\
\hline & $\begin{array}{l}\text { d) Kemampuan mempersilahkan siswa } \\
\text { untuk mempersentasikan hasil } \\
\text { diskusinya. }\end{array}$ & 3.50 & 3.50 & Baik \\
\hline & $\begin{array}{l}\text { e) Kemampuan mengarahkan siswa } \\
\text { menyelesaikan untuk kuis }\end{array}$ & 4.00 & 4.00 & Baik \\
\hline \multirow[t]{4}{*}{ III } & Penutup: & & & \\
\hline & $\begin{array}{l}\text { a) Kemampuan mengarahkan siswa } \\
\text { untuk membuat rangkuman materi } \\
\text { pelajaran }\end{array}$ & 3.50 & 3.50 & Baik \\
\hline & $\begin{array}{l}\text { b) Kemampuan memberikan tugas } \\
\text { mandiri (PR) }\end{array}$ & 4.00 & 4.00 & Baik \\
\hline & $\begin{array}{l}\text { c) Kemampuan menutup pelajaran } \\
\text { dengan berdo'a dan salam }\end{array}$ & 5.00 & 5.00 & $\begin{array}{l}\text { Sangat } \\
\text { Baik }\end{array}$ \\
\hline
\end{tabular}




\begin{tabular}{cccc} 
IV Kemampuan Mengelola Waktu & 3.00 & 3.00 & \\
\hline Total & 3.75 & Baik \\
\hline
\end{tabular}

Sumber Data: Pengolahan Data Hasil Penelitian

Tabel 4. Kemampuan guru dalam mengelola kelas pada siklus I

\begin{tabular}{|c|c|c|c|c|}
\hline \multirow{3}{*}{ No } & \multicolumn{4}{|l|}{ SIKLUS II } \\
\hline & \multirow[b]{2}{*}{ Aspek yang dinilai } & Pert I & Pert II & \multirow[b]{2}{*}{ Kategori } \\
\hline & & $\begin{array}{l}\text { Rata- } \\
\text { Rata }\end{array}$ & $\begin{array}{l}\text { Rata- } \\
\text { Rata }\end{array}$ & \\
\hline \multirow[t]{4}{*}{ I } & Kegiatan Awal: & & & \\
\hline & $\begin{array}{l}\text { a) Kemampuan membuka pelajaran } \\
\text { dengan do'a dan salam }\end{array}$ & 5.00 & 5.00 & $\begin{array}{c}\text { Sangat } \\
\text { Baik }\end{array}$ \\
\hline & $\begin{array}{l}\text { b) Kemampuan mengkomunikasikan } \\
\text { tujuan pembelajaran }\end{array}$ & 4.00 & 4.00 & Baik \\
\hline & c) Kemampuan memotivasi siswa & 4.00 & 4.00 & Baik \\
\hline \multirow[t]{6}{*}{ II } & Kegiatan Inti: & & & \\
\hline & $\begin{array}{l}\text { a) Kemampuan menyajikan materi } \\
\text { secara singkat dengan mengaitkan } \\
\text { dengan pengetahuan prasyarat } \\
\text { siswa }\end{array}$ & 4.00 & 4.00 & Baik \\
\hline & $\begin{array}{l}\text { b) Kemampuan membagikan LKS dan } \\
\text { media pembelajaran }\end{array}$ & 5.00 & 5.00 & $\begin{array}{c}\text { Sangat } \\
\text { Baik }\end{array}$ \\
\hline & $\begin{array}{l}\text { c) Kemampuan mengarahkan siswa } \\
\text { untuk berkelompok dan } \\
\text { menemukan jawaban serta } \\
\text { menyelesaikan LKS, dengan } \\
\text { memberikan bantuan terbatas. }\end{array}$ & 5.00 & 5.00 & $\begin{array}{l}\text { Sangat } \\
\text { Baik }\end{array}$ \\
\hline & $\begin{array}{l}\text { d) Kemampuan mempersilahkan } \\
\text { siswa untuk mempersentasikan } \\
\text { hasil diskusinya. }\end{array}$ & 5.00 & 5.00 & $\begin{array}{l}\text { Sangat } \\
\text { Baik }\end{array}$ \\
\hline & $\begin{array}{l}\text { e) Kemampuan mengarahkan siswa } \\
\text { menyelesaikan untuk kuis }\end{array}$ & 4.50 & 4.50 & Baik \\
\hline \multirow[t]{4}{*}{ III } & Penutup: & & & \\
\hline & $\begin{array}{l}\text { a) Kemampuan mengarahkan siswa } \\
\text { untuk membuat rangkuman materi } \\
\text { pelajaran }\end{array}$ & 4.50 & 4.50 & Baik \\
\hline & $\begin{array}{l}\text { b) Kemampuan memberikan tugas } \\
\text { mandiri (PR) }\end{array}$ & 4.50 & 4.50 & Baik \\
\hline & $\begin{array}{l}\text { c) Kemampuan menutup pelajaran } \\
\text { dengan do'a dan salam }\end{array}$ & 5.00 & 5.00 & $\begin{array}{c}\text { Sangat } \\
\text { Baik }\end{array}$ \\
\hline \multirow[t]{2}{*}{ IV } & Kemampuan Mengelola Waktu & 4.50 & 4.50 & Baik \\
\hline & Skor Rata-Rata & \multicolumn{2}{|c|}{4.58} & Baik \\
\hline
\end{tabular}

Sumber Data: Pengolahan Data Hasil Penelitian 
Implementasi Pendidikan Karakter...

\section{Penutup}

Berdasarkan hasil penelitian dan pembahasan, maka dapat disimpulkan beberapa hal sebagai berikut:

1. Implementasi pendidikan karakter dalam pembelajaran Matematika dengan menggunakan model pembelajaran kooperatif tipe Team Assisted Individualization dilaksanakan dengan cara: 1) pembagian materi dan LKS kepada siswa secara individual; 2) guru menyampaikan materi secara singkat; 3) siswa memahami materi dan mengerjakan LKS secara individual; 3) pembagian kelompok, yang terdiri dari 5 siswa; 4) di dalam kelompok, siswa saling memeriksa jawaban LKS; 5) presentasi oleh siswa dengan nilai tertinggi; 6) guru bersama dengan siswa membuat kesimpulan terkait dengan materi; dan 7) memberikan penghargaan kepada siswa dengan hasil belajar tertinggi. Dengan langkah-langkah tersebut peneliti dapat melihat peningkatan karakter disiplin, kerjasama, dan tanggung jawab siswa dalam pembelajaran. Hasilnya menunjukkan bahwa pada siklus I persentase karakter disiplin 98.67\%, kerjasama 96\%, dan tanggung jawab 86.71\%. Pada siklus II, 98.76\% siswa telah memiliki karakter disiplin, 96.90\% siswa memiliki karakter kerjasama, dan 88.89\% siswa telah memiliki karakter tanggung jawab. Hal ini membuktikan bahwa model pembelajaran kooperatif tipe Team Assisted Individualization mampu memotivasi siswa kelas V SD Negeri 3 Weda untuk memiliki karakter disiplin, kerjasama, dan tanggung jawab.

2. Implementasi pendidikan karakter juga dapat meningkatkan hasil belajar Matematika siswa kelas V SD Negeri 3 Weda pada materi bangun datar sederhana dengan menggunakan model pembelajaran kooperatif tipe Team Assisted Individualization. Ketuntasan belajar siswa dari 0\% meningkat pada siklus I menjadi 40\% dan siklus II 76\%. Hal yang sama dapat dilihat pada kemampuan guru dalam mengelola kelas, pada siklus I nilai guru 3,75 meningkat pada siklus II menjadi 4,58 dengan kategori baik. 


\section{Daftar Pustaka}

Azzet, Akhmad Muhaimin. 2011. Urgensi Pendidikan Karakter di Indonesia. Cet. I. Jogjakarta: Ar-Ruzz Media

Fitriana, Ida. 2005. Meningkatkan Hasil Belajar dan Sikap Konstruktif Terhadap Pembelajaran Waktu, Jarak, dan Kecepatan Melalui Model Pembelajaran Kooperatif STAD (Student Team Achievement Division) pada Siswa SMPN 2 Demak Tahun 2004/2005. Semarang: UNNES

Kesuma, Dharma. 2011. Pendidikan Karakter: Kajian Teori dan Praktik di Sekolah, Cet. ke-1, Bandung: PT. Remaja Rosdakarya

Sanjaya, Wina. 2011. Penelitian Tindakan Kelas, Edisi 1, Cet. 3. Jakarta: Kencana

Slavin, R.E. 2010. Team Assisted Cooperative Learning and individualized Instruction In The Mainstreamed Classroom. Search of journals. Hammil Institute on Disabilities.

Slavin, R.E. 1983. Team-Assisted Individualization: A Cooperative Learning Solution for Adaptive Instruction in Mathematics. Artikel.

Sumantri, Mulyani dan Johar Permana. 2011. Strategi Belajar Mengajar. Bandung: CV Maulana

Tim Asosiasi Lembaga Pendidikan Tenaga Kependidikan Indonesia, 2009. Pemikiran tentang Pendidikan Karakter dalam Bingkai Utuh Sistem Pendidikan Nasional. Jakarta.

Undang-Undang RI Nomor 20 Tahun 2003. Sistem Pendidikan Nasional Pasal 3

Washin, B \& Salend. J. S, Team-Assisted Individualization with Handicapped Adjudicated Youth. Artikel. Diakses pada tanggal 01 Desember 2015

Wiyani, Novan Ardy. 2013. Membumikan Pendidikan Karakter di sekolah di $S D$, Cetakan I. Jogjakarta: Ar-Ruzz Media

Wiyono, Hadi. 2012. Pendidikan Karakter Dalam Bingkai Pembelajaran di Sekolah. Jurnal Ilmiah CIVIS, Vol II (2) 